\title{
Transhumanism and Singularity: A Comparative Analysis of a Radical Perspective in Contemporary Works
}

\section{Transhümanizm ve Tekillik: Çağdaş Eserlerde Radikal Bir Perspektifin Karşılaştırmalı Analizi}

\author{
Timuçin Buğra EDMAN*
}

\begin{abstract}
A new literary tendency of the $21^{\text {st }}$ century has reached a certain level where it encapsulates both the past and future of humans. We call this tendency "transhumanism", and it endeavors to combine science and technology through the filtration of fantastic elements of literature to amalgamate the entity of man and the ideas of singularity and immortality. The selected three contemporary novels, namely Brave New World, Do Androids Dream of Electric Sheep? and The Transhumanist Wager brought a consolidation towards the initiated movement of transhumanism in literature. Therefore, in principal, the first aim of this article is to present how the basic logic of transhumanism embodied in the selected contemporary works. For this reason, a transhumanist analysis of works will be applied on them after an explanation of the different perceptions of transhumanism, since it is a fresh approach. A secondary objective of this text is to explain the idea of singularity and immortality in the $21^{\text {st }}$ century to demonstrate the journey of this ever-lasting desire. The continuation of this longing from ancient times to our own is not something astonishing, but the way this desire maintains and manifests itself through science and literature is worth mentioning.
\end{abstract}

KeyWords: Tranhumanism, Singularity, Immortality, Virtual Reality

$\ddot{O} z$

21. yüzyılın yeni bir edebi eğilimi, insanların hem geçmişini hem de geleceğini içine alan belirli bir düzeye ulaştı. Biz buna "transhümanizm" eğilimi diyoruz ve transhümanizm, insanın varlığını, tekillik ve ölümsüzlük fikirlerini birleştirmek için bilim ve teknolojiyi edebiyatın fantastik unsurlarının filtrelenmesi yoluyla birleştirmeye gayret eder. Üç çağdaş romanın seçimi, yani Cesur Yeni Dünya, Androidler Eletrikli Koyun Düşler Mi? ve Transhümanist Bahis, transhümanizmin başlatılan hareketine literatürde bir bütünleştirme getiriyor. Bu nedenle, bu makalenin ilk amacı, seçilmiş çağdaş eserlerde, transhümanizmin temel mantığının nasıl oluştuğunu ortaya koymaktır. Bu yüzden, yeni bir yaklaşım olduğu için, transhümanizmin farklı algılarının açıklanmasından sonra, eserlere transhümanist bir analiz uygulanacaktır. Bu metnin ikincil bir amacı, 21. yüzyıldaki tekillik ve ölümsüzlük fikrini açıklayarak bu ebedi arzunun yolculuğunu sergilemektir. Bu özlemin eski çağlardan başlayarak kendi başına devam etmesi şaşırtıcı bir şey değildir, ancak bu arzunun kendini bilim ve edebiyat aracılığıyla sürdürdüğü ve tezahür ettiği şeylerden bahsetmek ise kayda değerdir.

Anahtar Kelimeler: Transhümanizm, Tekillik, Ölümsüzlük, Sanal Gerçeklik

\section{Introduction}

It is true that since the creation of mankind, we have experienced the ups and downs of this world. To disengage from the disabilities and the limited capacity of our mortal bodies, we have created gods in our own form and we have practiced occult traditions and alchemy. In the world of myths and fantasies, humans created Talos, the half-humanoid and half-robotic creature of their dreams. The same humans fantasized about the hounds of Alcinous -ever mortal beings crafted by Hephaestus out of silver and gold. Dr. Frankenstein's monster was the product of the same intelligence, as was as the vision of Nexus 6 replicants in the postapocalyptic world of Do Androids Dream of Electric Sheep?. Throughout their radical and vertical evolution, most humans haven't wanted to accept death as an end. For this reason, ancient Mayans, Egyptians, Greeks, the Nordic Tribes, Celts, and so on all believed in alternative life stories which continued after their worldly extermination. Such a life changing ideology altered the lives of humans drastically. The imaginations of humans are reflected in the maxims of their literary creations as well. While striving for the limits of relatively momentary lives, shared memories and involvements gave way to scientific improvements.

\footnotetext{
* Dr. Öğr. Üyesi. İstanbul Aydın Üniversitesi, Fen-Edebiyat Fakültesi, İngiliz Dili ve Edebiyatı Bölümü, timucinedman@aydin.edu.tr
}

Edman, T. B. (2019). Transhumanism and Singularity: A Comparative Analysis of a Radical Perspective in Contemporary Works, Gaziantep University Journal of Social Sciences, 18 (1), 39-49 , Submission Date: 22-072018, Acceptance Date: 22-01-2019.

Araştırma Makalesi. 
Slowly, occultism has been swept away by science. What was once impossible became not a matter of fact but a matter of time, like in From The Earth To The Moon by Jules Verne. What sounded crazy yesterday might be possible today, as revolutionary science makes the craziest things the most ordinary things tomorrow. As the problems of this world grow, the leniency towards an alternative reality will grow immensely as well. People experience disillusionments with their surrounding reality, so they seek for an augmented or artificial asylum. This is not escapism, though. It is not an escapist perception of the world in the way it works, but an intriguing layer where humans can encrypt their hidden dreams into ultimate reality. As literature has always been the anchorage of the dream world of humanity, transhumanism marches forward from the past to reach out for a new possibility that we have yet to meet. Men and women will not be the only genders, and humans will not be the only clever species any more in this dimension. As in the example of the humanoid robot Sophia, technology is one step closer to imitating human form to either distract from or encompass the future, depending on how one perceives such a future. We can trigger a secondary annihilation, as occurred in Hiroshima or Chernobyl. Handicaps, disabilities and genetic sicknesses won't be part of our fate so long as technology is capable of producing revolutionary solutions to fix these problems while "the living thing" is just an embryo in the mother's womb, or in a laboratory like in Brave New World. An ardent follower of immortality may find themself in a confrontation with nearly the rest of society. It is most likely true that the idea of immortality will never find a compromise with modern religions, at least not in the very near future. Nevertheless, this doesn't stop people from having their bodies frozen at places such as the Alcor facility of the Cryonics Institute in Michigan. A contemporary novel, like The Transhumanist Wager, draws the worlds' state as a catastrophe. Stuck between modern religions and infantile dreams, a character like Jethro Knights might actualize an "experiential crossing." Moreover, the nature of evolution requires humanity to move forward. However, not all segments of society benefit equally from this progress. As economic acceleration deepens the gap between rich and poor, alternative quests and extraordinary developments are found to ensure social order. The $21^{\text {st }}$ century is full of hopelessness, just like the previous centuries. The wars, the endless struggle and the racial, religious and cultural partitions among societies have lasted since the first settled societies. This condition causes ill-fated and despondent people to search for alternative quests. As a solution, an anarchist viewpoint and revolutionary innovations that are created to stand against the current state of affairs will be a cause of a sub-creation, namely an alternative world. Undeniably, governments may also want to take advantage of this situation. It is much easier and safer to manage societies that are separated or categorized into classes and that do not go beyond the boundaries that the authorities draw. It may be possible to engage individuals with artificial and virtual realities to control them. Of course, this tendency will offer us the possibility of the existence of a new person who is thought to be a synthetic reality, suprahuman. A path that leads from mortality to immortality and transhumanism. What distinguishes us from other animals is our capability of hierarchical thinking based on reason and judgement. As Kurzweil stated,

\footnotetext{
The mammalian brain has a distinct aptitude not found in any other class of animal. We are capable of hierarchical thinking, of understanding a structure composed of diverse elements arranged in a pattern, representing that arrangement with a symbol, and then using that symbol as an element in a yet more elaborate configuration. This capability takes place in a brain structure called the neocortex, which in humans has achieved a threshold of sophistication and capacity such that we are able to call these patterns ideas. Through an unending recursive process, we are capable of building ideas that are ever more complex. We call this vast array of recursively linked ideas knowledge. Only Homo sapiens have a
}

\footnotetext{
${ }^{5}$ For some people, the fictional characters from books can exist beyond the page. In a recent study, researchers discovered that readers not only hear the voices of characters while they read, but that some also hear those voices when the book is closed (Sloat, 2017).
} 
knowledge base that itself evolves, grows exponentially, and is passed down from one generation to another. (Kurzweil, 2013, p. 3)

As each generation reaches a better level, humans start to seek a new shelter, a shelter that doesn't contain the problems of this world. Naturally, that calls for the aid of virtual reality as a substitute asylum. According to some, the alternative reality that creates something similar to the effect of LSD is post-anarchic rebellion. According to others, it is a new action developed by the governments and families that govern the world to provide control. Amid the possible conspiracy theories, this article aims to examine the theory of transhumanism through a comparison of three major contemporary works: A Brave New World, Do Androids Dream of Electric Sheep?, and The Transhumanist Wager. It should not be forgotten that the subject is a very up-to-date subject, and that the studies on it are both limited and involve different fields of science as well. Therefore, sometimes the boundaries between science and science fiction and dystopic or a utopic visions of the future are blurred.

The development of technology sky-rocketed after the $18^{\text {th }}$ century as the Industrial Revolution made solid progress that became synonymous with science and technology. In literature, as mentioned before, authors such as Wells and Verne forged the beginnings of modern science fiction while getting people ready for the upcoming events (Sirius \& Cornell, 2015 , p. 7). As the $20^{\text {th }}$ century opened, offering new dimensions for everyone, control of the state and the people became another question raised. Mass population movements and mass population destruction, as happened in two world wars and the protests and upheavals during the Vietnam War, made it necessary to rethink control and the leading mechanisms. Unlike the soft, milder and naturalist tendencies of the LSD-riddled youth, the rest of the century was a dilemma between war and peace through only technology. Therefore, technology, whether to protect a nation or to enable superiority of one over another, led to a tremendous consistency in the process of evolution. After the 1970's, the astonishing leap forward of home computers brought a new platform to everyone who sought an alternative explanation for the destruction going on around the world. With the introduction of computers to every home, computer coding opened a new era. It was later discovered that that the structure of human DNA can be well imitated through computer codes to create artificial life forms (Sirius \& Cornell, 2015). An artificial life form may or may not be the same as the real-life version, but the definition of reality is now blurred thanks to advanced VR technologies. ${ }^{6}$

In any case, what Huxley presented to us in his Brave New World surely opened a new dimension in front of us. Transforming human DNA into something that is desirable by governments used to be a very fantastic element, but with the implementation of new technology, if not for the benefit of the governments yet, DNA can be described as a form of body sculpting, where

[t]ranhumanist dreams of body sculpting tend to involve genetic and cyborgian techniques that may, on the one hand, give the recipient a conventionally impressive body or, on the other hand, may involve something more imaginative, including being able to switch genders at will. Or it could describe completely imaginary bodies in virtual spaces that, in fact, may become the major locus for our lives. (Sirius \& Cornell, 2015, p. 34)

When a human body loses its form as something solid that comes through creation, how can we define it as a human form anymore? With body sculpting, technology moves the boundaries beyond renovation. As in Huxley's Brave New World, the very next step could be a fastidious future where people will be labeled as Alphas, Gammas and Betas before they are

\footnotetext{
6 "The definition of virtual reality comes, naturally, from the definitions for both 'virtual' and 'reality'. The definition of 'virtual' is near and reality is what we experience as human beings. So the term 'virtual reality' basically means 'near-reality'. This could, of course, mean anything, but it usually refers to a specific type of reality emulation" ("What is Virtual Reality?", 2018).
} 
born. Or else, as we see in Do Androids Dream of Electric Sheep?, we might live in a world where we don't have real animals anymore, instead we have life-size realistic cybernetic animals. Besides, it might become very hard to distinguish humans from cyborgs in a very near future. Behind all this development lies humans' great desire for control and hegemony. As in the thousands of years slavery, utmost control over the machine, or human-like cyborgs, would give humans god-like superiority and a way to immortality at least through self-satisfaction. Having displayed the general characteristics of transhumanism, its relationship with history is another matter to be discussed. Consequently, both science and technology might bring singularity and immortality to humanity as an alternative reality, as the novels which will be analyzed in this paper suggest.

\section{Transhumanism and Literature: An Introduction to a New Era}

Humanity's aim of achieving immortality is as old as the history of humanity, and the search for a longer and better life has stimulated us to go to the extremes of our capabilities as humans, as can be seen even in the oldest myths (Bostrom, 2016, p. 1). One of the oldest literary works, the Epic of Gilgamesh, is the story of a legendary Mesopotamian ruler, Gilgamesh, who searches for an everlasting life. From Beowulf to Achilles, Faust to Victor Frankenstein, we see many characters whose primary aim is to enter the void of eternity, thus becoming gods. As O'Connell stressed, "All utopian futures are, in one way or another, revisionist readings of a mythical past" (O'Connell, 2018, p. 51). Though these early works blend alchemy and magic, today technological and scientific developments in many disciplines have enabled humans to make their lives better and maintain their war against god or gods since the possibility of living forever remains the highest target of all the achievements (O'Connell, 2018, pp. 2-15).

According to David Livingstone, "Transhumanism is the quest to use all the advances of modern science to augment human potential, and ultimately, to achieve immortality" (Livingstone, 2015, p. 5). Livingstone argued that transhumanism has its roots in "occult" culture, which has "mysticism" at its core, that is, it asserts a person can become one with "God" through the use of "magic" (p.7). Mystics believe that the most essential source of "knowledge" is "magic", so it can be said that the practice of magic (or alchemy) brings forth "divine" knowledge to man, thusly "elevating man to the status of God" (pp.13-16). Kurzweil asserted that considering J. K. Rowling's Harry Potter stories from an imaginary perspective to reality is not inconceivable at all. Consistent with what Kurzweil said, "these tales may be imaginary, but they are not unreasonable visions of our world as it will exist only a few decades from now. Essentially all of the Potter 'magic' will be realized through the technologies" (Kurzweil, 2013, pp. 13-16).

One of the underlying principles of transhumanism is that man has the ability to be like God, to create and give life, as Zeus or Odin breathe life into non-living things to make them animated and thus transform them into human-beings. Therefore, from mythical times to now, humanity "is from the essence of God" or gods (Livingstone, 2015, pp. 5-8). Transhumanism is the ultimate combination of man and machine. It is the top layer of evolution, where the human body embraces immortality not simply as a maxim but as a solid fact. The quest for immortality results from the inadequacy and inequality of man. While weaker types become weak to the point of total annihilation, the strong reach a level where they must strive for more power and eventually vie for supremacy among themselves. To become better in every field, as Lewis Mumford proclaimed in his book Technics and Civilization, "Whatever limits the actions of human beings to their bare mechanical elements belongs to the physiology, if not the mechanics, of the machine age" (Mumford, 2010, p. 41), so a revolutionary leap forward becomes a fact of human life in order to keep pace with the ever-changing world and technology. Peter Kropotkin asserted that: 
There are periods in the life of human society when revolution becomes an imperative necessity, when it proclaims itself as inevitable. New ideas germinate everywhere, seeking to force their way into the light, to find an application in life; everywhere they are opposed by the inertia of those whose interest it is to maintain the old order; they suffocate in the stifling atmosphere of prejudice and traditions. (Kropotkin, 2003, p. 7)

When the older order resists the new one, like the clash of the oppositions, a new beginning will come. Being an ardent English author, Aldous Huxley was heavily influenced by Kropotkin's philosophy. Huxley's 1932 dystopian novel Brave New World propounded that an incoming financial confusion and redundancy will trigger an extreme response in the form of a so-called global fixation on human transcendence. In this world, the "World State's motto, is COMMUNITY, IDENTITY, STABILITY." (Huxley, 1978, p. 1) Humans became "major instruments of social stability. Standard men and women; in uniform batches" (Huxley, p. 3). In establishing subservient human forms, governments put lots of effort into crafting "perfect" models through trial and error. In the human stock-raising labs, men "[would] grow up with what the psychologists used to call an 'instinctive' hatred of books and flowers. Reflexes unalterably conditioned. They'll be safe from books and botany all their lives" (p. 12). Flowers would be a loss of time and might distract people as they are evocative of nature. Books, of course, were considered the source of evil, and to potentially direct people to question many things. Thus, the government was fixated on making people hate books. Both a sense of ownership and feelings of belonging were the essences of rebellion and evil since "everyone belongs to everyone else" (p. 24). The elimination of the sense of belonging of individuals brought meaninglessness into Huxley's world. Hopes were disappearing at the point where the desire and will to live vanished. Lacking a sense of belongingness created a world which is totally alienated for anyone. Of course, the creation of such a discrete society was quite positive for the administration. Because the more disorganized the society would be, the more likely they would remain silent and obey the system. Still, a world where everyone is everyone else's property and labeled as alphas and betas should be controlled and cured somehow. Defeat, grief, and belonging were thought to have been made to display themselves as the manifestation of instable human actions, and consequently the individuals of Huxley's London sought the need to cure those flawlessly natural human feelings with soma to neutralize their rebellious forethoughts: "'You do look glum! What you need is a gramme of soma.' Diving into his righthand trouser-pocket, Benito produced a phial. 'One cubic centimetre cures ten gloomy. But, I say!"” (p. 41). Benito offered Bernard some soma because it was vital to be like an outsider or misfit through soma to demarcate the difference of society and the individual who takes the soma. This application was also a form of remedy, since even for a while the people were able to find another dimension psychologically, if not physically, to escape from the rest of the society. Apart from a partial acquaintance that Bernard had towards human experience, the environment he subsisted in had no difference:

Benito stared after him. 'What can be the matter with the fellow?' he wondered, and, shaking his head, decided that the story about the alcohol having been put into the poor chap's blood-surrogate must be true. 'Touched his brain, I suppose. (p. 41)

It can be presumed that Bernard and Lenina could not think clearly enough to comprehend themselves due to the hormonal transformations carried out on fetuses in London. Alcohol was fused into genes so that the public would not complain about the social class they were "designed" to be a part of. Nevertheless, since the government seeded false ideas and dreams into their brains under the inspiration of Henry Ford and his "T model," humans were incapable of acting normally. As it was stated in Science Fiction And Philosophy From Time Travel To Superintelligence, "unfortunately, despite Aristotle's claim that 'man is the rational animal,' human beings are prone to behaving in an irrational fashion when their interests are threatened, and they must deal with beings/entities they perceive as being different from 
themselves" (Schneider, 2009, p. 261). In the dystopic "Brave New World", humans have to deal with the government and its institutions that proclaim to be the god. "[O]ne believes things because one has been conditioned to believe them. Finding bad reasons for what one believes for other bad reasons-that's philosophy. People believe in God because they've been conditioned to" (Huxley, 1978, p. 160). We see a dystopian future displayed by Huxley, where our lives are controlled by ultimate governments whose mission is to destabilize variety in human thinking and thus psychology as well. What the government in Huxley's novel tried to achieve is a fundamental race of "transhumans" who are programmed to do certain things and follow the meticulously designed behaviors which have been integrated to their DNA codes in labs. Through genetic implementations, they have revolutionized people (if not in a positive way) by making and boosting their capabilities to benefit from their labour. In other words, by applying scientific nuances they classified the human body and turned it into an irrational machine or slave. This is an early transhumanist view that foresees the future of man in perfected physiologies or bodies thanks to technology, but totally enslaved by the same technology. Consequently, the people who were shaped by the system were actually singularized and became slaves of the system. In this way, it was possible for the sovereigns to make people more obedient rather than taking them into a further level of civilized humanity with technology.

Another transhumanist novel is Do Androids Dream of Electric Sheep?, by Philip Kindred Dick, whose fantasy world is still affecting today's real world on technology, philosophy, literature and the film industry. In this novel, we have a dystopic onset by an android hunter Rick Deckard, who has been given a job to hunt down new Nexus 7 models alongside another replicant Nexus 7, Rachael. These androids were given some false dreams to create a kind of fake reality to make them believe that they do have a past life, since they have been filled with "memories." For this reason, in some cases, even the androids were not aware of the fact that they are not humans. In fact, it is true that today scientists are trying to find ways to install the memory of humans into a cloud-like application so that their memories can be installed into a machine. There are many scientific developments which are leading the way to this technology. ${ }^{7}$ Even TV series like Black Mirror put lots of emphasis on this technological possibility. Moreover, according to Kurzweil, "by 2045, technology will have surpassed human brainpower to create a kind of superintelligence - an event known as the singularity. Other scientists have said that robots will overtake humans by 2100." ${ }^{\prime 8}$ Like Kurzweil suggested for reality, in the fictional world of Do Androids Dream of Electric Sheep?, the only way to distinguish androids from humans is the Voigt-Kampf test, and new model androids are very difficult to detect:

"In a magazine you come across a full-page color picture of a nude girl." He paused. 'Is this testing whether I'm an android,' Rachael asked tartly, 'or whether I'm homosexual?'" The gauges did not register" (Dick, 2008, p. 49). In such a very indirect question, Rachael responds very quickly and directly to Deckard. It seems androids have come to an understanding of sexual reprimands as well. The difference between a human and an android can be so tiny that even it could be microcosmic. Throughout the novel, readers think Deckard may even be an android. The details that distinguish between Android and human beings have been minimized by the ultimate technology, so understanding these differences is only possible in a laboratory environment after hunting androids. These realistic androids even stunned Deckard, whose main job was to hunt down and destroy them. Deckard was no longer sure what was real and what was artificial. The things he felt for Rachel were the most solid indicators of his dilemma. Therefore, in the novel, Deckard couldn't tell what was more attractive to him: on the one hand

\footnotetext{
7 ("Mind Uploading", 2018)

${ }^{8}$ (Lewis, “The Singularity Is Near: Mind Uploading by 2045?”, 2013)
} 
there was Iran, his wife, with no enthusiasm but with a certain sexual digression, on the other hand there was Rachael, an android which or who was seductive and attractive:

He wondered, now, about her, too. Some female androids seemed to him pretty; he had found himself physically attracted by several, and it was an odd sensation, knowing intellectually that they were machines, but emotionally reacting anyhow. (Dick, 2008, p. 95)

Another question is to whether classify androids as humans or mere machines: You're androids,' Isidore said. But he didn't care; it made no difference to him. 'I see why they want to kill you,' he said. 'Actually, you're not alive(p. 163).

If someone kills an android, would it be a real homicide, or as Asimov once called it, would it be a "roboticide?" ${ }^{9}$ Nonetheless, also Dick entered this dangerous area by asking questions to find what really differentiates humans from androids. Is it our souls -if we accept that we have souls- or is it our brains that differentiate us? Today as mentioned earlier, we know that neuroscientists are trying to upload human minds into machines, and for them, the soul is the mind and mind is the soul of humankind. In a way, the border between machines and humans seem to lessen through the use of highly developed artificial intelligence, which can even mimic human reason and reactions to a certain extent. After all, androids lack of emotional experience with only limited time to record their knowledge, which normally humans take for granted. Had the androids given an artificial past, this would construct an artificial and emotional "infrastructure" for them to mimic human emotions. In such a state, as in Do Androids Dream of Electric Sheep?, the border between humans and androids become more transparent, and it becomes barely visible at the end. Even such possibilities might trigger an option for the human mind to be uploaded to machines to store memories eternally. This is another stage of transhumanism when the quality of being humans are blended with technology to come up with androids disguised in human forms or humans that live in android subsistence. This can be seen as one of the ultimate goals of transhumanism, as also described in the novel: Androids with emotions and humans with unlimited possibilities where they exceed the limits of their bodies and minds. Indubitably, such a combination would be the dangerous path of the human beings towards a divine being. Therefore, this phenomenon, which can be a conflict with religious beliefs, will cause a completely different battle because of the human being's desire to play God. It is possible to say that a similar conclusion is envisaged by Dick in the novel. As in Huxley's Brave New World, Dick's world had no modern religion, instead what they had was Mercerism and an "empathy box" to replace their conscience and fix their feelings. The first uprooting of society starts due to the limitations of religions that tell people where to stop and cease playing gods. The self-demolishing of mankind appears once they play the role of God, as in the ancient stories of Noah's Flood, the myth of Atlantis or the curse of the pharaoh who fought against Moses.

The old man said, 'You will be required to do wrong no matter where you go. It is the basic condition of life, to be required to violate your own identity. At some time, every creature which lives must do so. It is the ultimate shadow, the defeat of creation; this is the curse at work, the curse that feeds on all life. Everywhere in the universe.' (p. 179)

Today, it is a well-known fact that the proximity between man and machines is getting closer. Many biological obstacles are being by-passed through new innovations. This merging will eventually bring the concept of singularity to the surface. In his groundbreaking The Singularity Is Near: When Humans Transcend Biology, Kurzweil put forward the hypothesis that

The Singularity will represent the culmination of the merger of our biological thinking and existence with our technology, resulting in a world that is still human but that transcends our biological roots. There will

\footnotetext{
${ }^{9}$ Having mentioned Asimov, actually, the ethics of androids and their rights can be traced through Isaac Asimov and his famous Robot Series, entangled with three famous laws, however that should be another discussion.
} 
be no distinction, post-Singularity, between human and machine or between physical and virtual reality. If you wonder what will remain unequivocally human in such a world, it's simply this quality: ours is the species that inherently seeks to extend its physical and mental reach beyond current limitations. The Singularity will allow us to transcend these limitations of our biological bodies and brains. We will gain power over our fates. Our mortality will be in our own hands. We will be able to live as long as we want (a subtly different statement from saying we will live forever). We will fully understand human thinking and will vastly extend and expand its reach. By the end of this century, the nonbiological portion of our intelligence will be trillions of trillions of times more powerful than unaided human intelligence. (Kurzweil, 2005, p. 9)

People see themselves as intelligent beings because of the mental capabilities of human brain, and this fact is important in everyday life. Engendered artificial intelligence and human brains will somehow strive for a longer life when the human body transcends its boundaries. However, there are more and more works appearing that scrutinize the very limits of transhumanism. Another literary work on transhumanism is a recent one. The Transhumanist Wager by Zoltan Istvan. In this half-novel, half-theoretical book, Istvan introduces us to Jethro Knights, an adamant transhumanist who sees all religions and conventional thoughts as obstacles in front of human evolution. His chief enemy, reverend Belinas, and Knights himself drew an axis of symmetry to display two extreme lines of thoughts:

The conflict over transhumanism was straightforward. Futurists, technologists, and scientists touted transhuman fields like cryonics, cloning, artificial intelligence, bionics, stem cell therapy, robotics, and genetic engineering as their moral and evolutionary right - and as crucial future drivers of the new economy and an advancing cultural mindset. (Istvan, 2013, p. 7)

While the conventional thought is against this very dangerous idea, some scientists defended the unlimited possibilities through transhumanism and crossing the limits of human body. In the book, Istvan displayed a good example of how transhumanism will be seen by many today:

Opponents said transhumanism and its immortality mantra were anti-theistic, immoral, not humanitarian, and steeped in blasphemous egoism. They insisted that significantly altering the human condition and people's bodies via science and technology was the devil's work, regardless of how lucrative it might be for the economy. Many opponents said transhumanism was proof the end times was coming. (p. 7)

As stated before, transhumanism is also a way of playing the role of God. To do it, first the existing God should somehow vanish. The discussion between Cohen and Dr. Langmore was strange enough to show this cul-de-sac:

Thirty blocks away, Dr. Preston Langmore looked cautiously out his building's front door, on Canal Street in Manhattan's Lower East Side, before walking outside. He was one of the key 'immortality players,' as the media liked to call transhumanists, because their principal drive was to reach an unending sentience for themselves. Their route gave them ample distance between the thousands of expected protestors, many of whom were there on orders from Reverend Belinas, the rising religious star of the anti-transhumanist opposition. The preacher's advocacy of blatant aggression to anything transhuman was rumored to be triggering much of the recent terrorism in the country. Langmore was visibly paranoid, checking behind him every fifteen seconds to see if they were being followed. Cohen was unfazed. 'They want to burn us at the stake,' Langmore whispered, when he caught a glimpse of the rowdy masses near the rotunda's front entrance. Barricaded by dozens of nervous police, an ocean of screaming, faith-touting protesters thrust incendiary posters into the air. 'Well, we do want to kill their god.' 'I thought you just wanted to clone it. (p. 8)

Jethro Knights doubted whether the world was staggering towards the brink of a second Dark Ages. His took a journey back to "Galileo, Copernicus, and Giordano Bruno-scientists who were chastised or burned at the stake for their revolutionary ideas that later propelled civilization forward" (p. 30). Jethro thought life was passing through a statistically pertinent and significant universe. There was no place for blind optimism when death was certain for all species. "It was no place for allowing stupidity and irrationality when you had one shot to live forever. The battle was on for his existence" (p. 68). Since no one knows what really lies beyond 
death, this inevitable fact should be challenged as the Wright brothers challenged gravity, or as Einstein changed the course of physics, and how we look at the rest of the universe. Jethro Knights is a fictional character who might inspire someone as scientists have been inspired by another fictional character, Michael Arden, who came up with brilliant ideas for the Moon trip in From the Earth to the Moon.

Through the rest of the book, Istvan blended a harsh criticism of American capitalism through transhumanism. It became apparent that through Knights, Istvan elaborated on the fact that Americans, or the system that they represent, is nothing but a mere illusion: "You people want to pretend that democracy, religious inspiration, and unbridled consumerism are going to last forever and carry us all to bliss; that the American Dream is right around the next corner for everyone" (p. 127). For Jethro, people who made us blind are the same as the people

\begin{abstract}
...who made sugary colas more important than water; fast food more important than health; television sitcoms more important than reading literature. They made smoking a joint in your home a crime; going out in public without your hair tinted an embarrassment, and accidentally carrying a half-filled bottle of baby formula on an airplane a terrorist act. Their trio of holy catechisms is: faith is more important than reason; inputs are more important than outcomes; hope is more important than reality. Their greatest achievement was the creation of the two-party political system; it gave the illusion of choice, but never offered any change; it promised freedom, but only delivered more limits. In the end, you got stuck with two leading loser parties and not just one. Look anywhere you go. America is a nation of submissive, dumbed-down, codependent, faith-minded zombies obsessed with celebrity gossip, buying unnecessary goods, and socializing without purpose on their electronic gadgets. (p. 155)
\end{abstract}

At the end of the novel, Jethro Knights could raise a large enough amount of money to enable his dreams to come true. He hired scientists from different fields to work freely on his floating arc without being on any land of other countries. Governments use money to develop technologies in a way to create dominance over each other, but not to expand human lives:

Every time they accept anti-science laws instead of pro-science laws, every time they embrace restrictive religious attitudes instead of freethinking human enhancement attitudes, every time they pay for trilliondollar wars abroad instead of funding trillion-dollar wars at home against cancer, heart disease, or old age, they are prematurely ending the lives of their fellow human beings. (p.245)

With the technology he had developed via his scientists, Jethro managed to overcome the armies of the world; he controlled his super lanes and robots remotely to devastate united armies of the world. It should be remembered that even the most powerful technologies are sometimes very weak, even if this kind of victory against all countries of the world in Istvan's novel is relatively fast and sudden. As in H.G. Wells' The War of the Worlds, sometimes even a small bacterium or virus can wipe out colossal civilizations or technologies, and an unknown technology can destroy all existing technologies as well. For example, a well-developed program that can cut the entire signal and communication network may be sufficient for this. Finally, Jethro's doctrine of transforming human knowledge to merge with machines created the proto beginnings of his transhumanist dreams. Expanding life became possible when even Jethro himself was infected with a deadly virus. Through cryonics, he got his body frozen so that he could be salvaged in the future when certain remedies would become available. These are all good examples to show that possibilities are numerous if science is used properly to extend human life and transform the physical body into a "superman" form. The point where transhumanism and science merged is actually a symbiosis. One cannot exist without the other, but the combination of the two phenomena will ultimately bring the chain of infinite possibilities. This creates the fundamental part of transhumanism: Exceeding the limits of earthly bodies. 


\section{Conclusion}

As it happened to John at the end of Brave New World, a self-imposed exile in a digital world could be the very end of humans. Or we could be stabbed in the back, like how Deckard fell into Rachael's hands in Philip K. Dick's world. Stephen Hawking warned us that "Artificial intelligence could wipe out humanity when it gets too clever, as humans will be like ants."10 This is the expected end of one of the $21^{\text {st }}$ century's last geniuses, who predicted it before his death. In this or that way, whatever Jethro achieved is an allusion to what transhumanists might achieve at the cost of total annihilation or a digital form of immortality. Modern religions and institutions might become more vulnerable against today's technology, which offers many solutions and vast ideas beyond yesterday's imagination. History might repeat itself, like when the Church accepted after the geographical explorations that actually there had been "no monsters" below the surface of the Atlantic Ocean. ${ }^{11}$ Mankind might more like the idea of having an eternal life and servants like robots. As Steve Wozniak declared, robots would treat us with reverence and gentleness, with an aristocratic generosity, because we humans were the gods initially, and our ever-lasting desire to become like gods will seemingly never decline as our power rises gradually. As Huxley imagined, we already have proto transhumans in test-tube baby labs where doctors are able to make some minor changes to lower some health risks of the unborn infants. It is highly possible that empowering their intelligence level as well as implementing some skills will be real, too, as Huxley foresaw. Genetic intervention will allow future generations to be stronger and healthier to fit into tough working conditions, whether this would evoke a dystopia or a utopia, but such genetic interventions might cause new developments whereby the human body and consciousness merge with artificial android organisms, as Philip Dick suggested. And this can be only conceivable through funding technology to find new ways to make humans immortal, or at least to fix health problems to expand the life cycle on earth. Genetically and technologically modified bodies might reveal entities like Jethro Knights who adamantly dedicated himself to sustain a transhumanist world.

\section{References}

Arısoy, Sercan. (2018). Analysis of linguistic knowledge and capability's effect on consciousness: linguistic approach to Aldous Huxley's brave new world

Bostrom, N. (2016). Superintelligence: paths, dangers, strategies. Oxford: Oxford University Press.

Dick, P. K. (2008). Do androids dream of electric sheep?: the inspiration for the films blade runner and blade runner 2049 (Kindle Edition ed.) [Kindle Version].

Griffin, A. (2015, October 09). Artificial intelligence is going to get so good that machines will kill us by accident, Stephen Hawking says. 18/02/2018, retrieved from https://www.independent.co.uk/life-style/gadgets-and-tech/news/stephen-hawkingartificial-intelligence-could-wipe-out-humanity-when-it-gets-too-clever-as-humansa6686496.html

Huxley, A. (1978). Brave new world. New York: Harper \& Row.

Istvan, Z. (2013). The transhumanist wager (Kindle ed.) [Futurity Imagine Media LLC].

Kurzweil, R. (2005). The singularity is near: when humans transcend biology. New York: Viking.

Kurzweil, R. (2013). How to create a mind the secret of human thought revealed. New York: Penguin.

Kropotkin, P. (2003). Anarchism. New York: Dover Publications.

\footnotetext{
${ }^{10}$ (Griffin, "Artificial intelligence is going to get so good that machines will kill us by accident, Stephen Hawking says", 2015)

${ }^{11}$ In the European Middle Ages, it was believed that monsters might exist in the ocean.
} 
Lewis, T. (2013, June 17). The singularity is near: mind uploading by 2045? 09/03/2018, retrieved from https://www.livescience.com/37499-immortality-by-2045conference.html

Livingstone, D. (2015). Transhumanism: the history of a dangerous idea. S.1.: Sabilillah Publications.

Mind Uploading. (n.d.). 03/01/2018, retrieved from http://www.minduploading.org/

Mumford, L. (2010). Technics and civilization (University of Chicago Edition ed.). USA: The University of Chicago Press.

O'Connell, M. (2018). To be a machine: adventures among cyborgs, utopians, hackers, and the futurists solving the modest problem of death. New York: Anchor Books.

Özenc, Ardeniz. (2018). Transhumanism and gnosticism in christopher marlowe's doctor faustus

Schneider, S. (Ed.). (2009). Science fiction and philosophy from time travel to superintelligence. Malden (Mass.): Wiley-Blackwell.

Sirius, R. U., \& Cornell, J. (2015). Transcendence: the disinformation encyclopedia of transhumanism and the singularity. San Francisco (CA): Disinformation Books.

Sloat, S. (2017, February 15). One fifth of readers experience this auditory hallucination after reading harry potter. 04/04/2018, retrieved from https://www.inverse.com/article/27820-character-inner-voices-hermione-experientialcrossing

Wells, H. G. (2014). The war of the worlds. S.L.: Millennium Publications.

What is Virtual Reality? (n.d.). 04/04/2018, retrieved from https://www.vrs.org.uk/virtualreality/what-is-virtual-reality.html. 